\title{
Geospatial Assessment of the Impact of Urban Sprawl in Akure, Southwestern Nigeria
}

\author{
Victor A. Usman ${ }^{1}$, Esther 0. Makinde ${ }^{2}$, Ayobami T. Salami ${ }^{3}$ \\ ${ }^{1}$ Institute of Ecology and Environmental Studies, Obafemi Awolowo University, Ile-Ife, Nigeria \\ ${ }^{2}$ Laboratory for Geoinformatics Research, Department of Surveying and Geoinformatics, Faculty of Engineering, University of \\ Lagos, Lagos, Nigeria \\ ${ }^{3}$ Space Applications \& Environmental Science Laboratory, Institute of Ecology \& Environmental Studies, Obafemi Awolowo \\ University, Ile-Ife, Nigeria \\ Email: `greatestvictor4ever@yahoo.com, estherdanisi@gmail.com, eomakinde@unilag.edu.ng, ayobasalami@yahoo.com, \\ asalami@oauife.edu.ng
}

How to cite this paper: Usman, V.A., Makinde, E.O. and Salami, A.T. (2018) Geospatial Assessment of the Impact of Urban Sprawl in Akure, Southwestern Nigeria. Journal of Geoscience and Environment Protection, 6, 123-140.

https://doi.org/10.4236/gep.2018.64008

Received: January 16, 2018

Accepted: April 1, 2018

Published: April 4, 2018

Copyright $(9) 2018$ by authors and Scientific Research Publishing Inc. This work is licensed under the Creative Commons Attribution International License (CC BY 4.0).

http://creativecommons.org/licenses/by/4.0/

\begin{abstract}
This study analyzed trend and examined the factors responsible for urban sprawl in Akure with a view to develop a user-friendly geospatial database for monitoring urban sprawl in the study area. Medium resolution satellite imageries derived from Landsat (TM) and (ETM+) comprising of four dates (1986, 1991, 2002 and 2011) were analyzed. The results revealed that built-up area increased rapidly by $43.31 \%$ from 5857.54 hectares in 1986 to 8394.21 hectares in 1991. It further increased by $72.02 \%$ from 8762.76 hectares to 15073.7 hectares in 2011. Field study conducted in 2013 involved in-depth interviews and questionnaires to stakeholders and residence respectively. The analysis showed that there was a weak negative relationship $(\mathrm{r}=-0.189, \mathrm{p}<$ 0.01 ) between gender and "house ownership", a weak positive relationship ( $r$ $=0.343, \mathrm{p}<0.01)$ between marital status and "house ownership" and a weak negative relationship $(\mathrm{r}=-0.159, \mathrm{p}<0.05)$ between "number of children" and "house ownership" in the sprawl location. Geo-spatial database modeled was tested by subjecting it to spatial analysis to show its capability to answer question pertaining to all the entities of the database. The study concluded that urban sprawl increased and if not reversed, might constitute greater social and environmental problems in the future.
\end{abstract}

\section{Keywords}

Remote Sensing, Geodatabase, Land Use, Land Cover, Urban Sprawl, Global Positioning System (GPS) 


\section{Introduction}

Urban Sprawl is unplanned, uninterrupted monotonous developments that does not provide for a functional mix of uses and which variously appears as low-density, ribbon or strip, scattered, leapfrog discontinuous development and inefficient use of land [1]. According to [2], urban sprawl as a pattern in an urbanized area that exhibits some combination of eight distinct dimensions such as density, continuity, concentration, clustering, centrality, nuclearity, mixed uses and proximity. These dimensions eliminate agricultural lands, pollute water quality, and cause air pollution [3]. It can be reported that urban sprawl is a phenomenon that emanates from uncontrolled or uncontrollable expansion of the built-up areas of cities or an aftermath of many societal inefficiencies and mismanagement [4]. This is evident in the poor environmental qualities of many Nigerian cities. Also, [5] noted the rapid urban expansion that ensued has resulted in direct conversion of farmland which satisfies the demand for residential, commercial and industrial land uses, and directly reduces the agricultural potential of the remaining farms. For instance, in some states in Nigeria, lands adjoining major cities acquired by government are left unutilized for decades, thus forcing developers to jump over such lands to other areas in the same environment to develop new settlements which often grow to the level of urban centers within a short time. Mowe and Ibafo along Lagos-Ibadan expressway are good examples of such settlements.

Population increases, so do the needs for new facilities, amenities and decentralization from the urban core and precious farmland is often left unprotected from commercial or residential developers [6] [7]. These result into land use/land cover (LULC) changes. It is reported by [8] that land use/land cover (LULC) change is a key driver of global change. [9] noted that changes in land cover and in the way people use the land have become recognized over the last 15 years as important global environmental changes in their own right. In Nigeria, several studies on LULC using maps, aerial photographs and satellites imageries have been documented [10] [11] [12] [13] [14]. Also, it is reported that several factors such as agricultural colonization [15], spread of rural settlements [16], evolution of rural road networks [17] and government policy [18] noted in [19] have modified the original form of land cover in Nigeria. Yet, there remains a need for the development of basic datasets providing quantitative and spatial land use/land cover information. Moreover, there appears to be gaps in the available scientific information at national and local scales for use in regional and national decision-making process and rational planning. The same is true in the south-western part of Nigeria [8]. Despite the great economic importance of this region, there have not been systematic studies of land use/land cover changes [10]. The land use and land cover of any particular region is an outcome of both natural and socio-economic factors and their utilization by man in time and space. Land is becoming a scarce commodity due to immense agricultural 
and demographic pressure. Hence, information on land use and land cover and possibilities for their optimal use is essential for the selection, planning and implementation of land uses' schemes to meet the increasing demands for basic human needs and welfare [20].

The use of geospatial technique to assess urban sprawl cannot be over emphasised. The data derived from these techniques and its analysis provides new insights into the interaction of geographic phenomena [21]. Several studies have been conducted with the integration of remote sensing and geographic information systems to analyze and monitor land cover changes and urban sprawl [22] [23] and [24]. The ability to analyze and monitor land use and land cover change and urban sprawl will depend on our ability to understand the past, present and future state of land use and land cover change. This ability is enabled through the use of multi temporal remote sensing data and or aerial photographs which provides valuable information of natural resources like land, water, forests, urban areas and infrastructure facilities such as road network, river network etc. [25]. Using the Geospatial approach, database can be created that can evoke graphical response and answer questions pertaining to all the entities of the database.

The share of population living in urban areas increased from $20.2 \%$ in 1971 to $23.7 \%$ in 1981 and to $26.1 \%$ in 1991 [22]. However, these figures do not tell the whole story. The antecedent impact on the physical development constitutes a major concern. Although there have been studies on the rapid urbanization and urban sprawl of cities in the developing countries and in Nigeria, there has not been major scientific prove of the impact of urban sprawl in Akure area of Ondo State, hence this study. This study uses remotely sensed multi-temporal satellite imageries and field survey to assess urban sprawl and its impact in Akure. Also, a geospatial database for the study area was also created using geospatial techniques.

\section{Materials and Methods}

\subsection{The Study Area}

Akure, the state capital of Ondo State, lies between latitudes $7^{\circ} 12^{\prime} \mathrm{N}, 7^{\circ} 19^{\prime} \mathrm{N}$ and longitudes $5^{\circ} 08^{\prime} \mathrm{E}, 5^{\circ} 18^{\prime} \mathrm{E}$ (Figure 1). It is situated within a 48 kilometer radius to major towns in the State, vizOndo to the South, Owo to the East and Iju/ItaOgbolu to the North. The area falls within the tropical humid climate that is characterized by wet and dry seasons. The mean annual rainfall of the area is $1220 \mathrm{~mm}$, while the mean annual temperature is about $27^{\circ} \mathrm{C}$ and its mean annual relative humidity is about $77.1 \%$ [26]. The rapid growth of the city has made it one of the fastest growing metropolitan areas in the South-western Nigeria with the population increasing from 71,006 in 1963 to 239,124 in 1999 ; and by 2006 , the total population had increased to 340,021 inhabitant [27] NPC 1991. The population is projected to be 1.8 million people in 2015 [28]. The population of Akure 


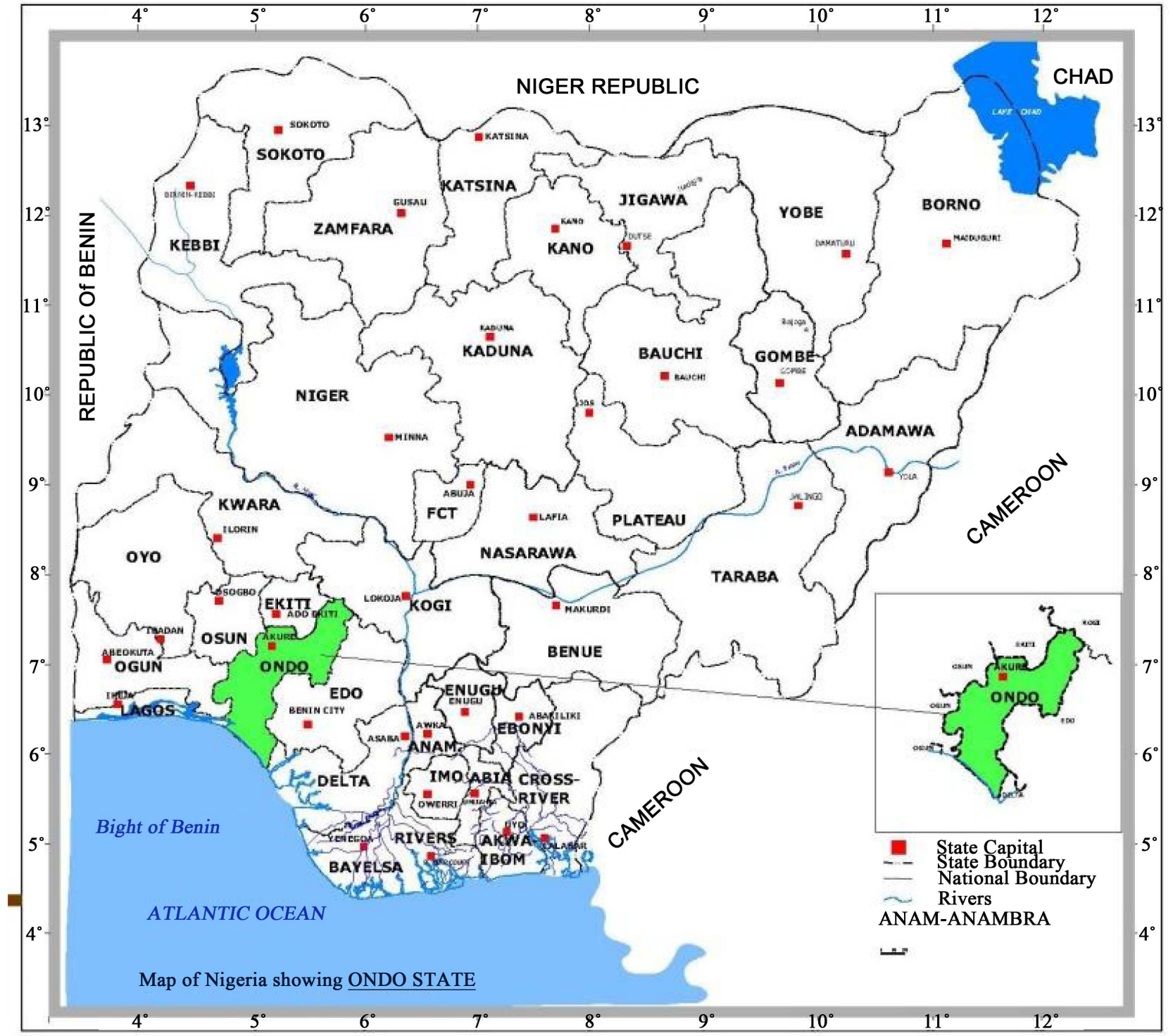

Figure 1. Map of Nigeria showing Akure—the Study Area, in Ondo State. Source: Ministry of Housing and Urban Development (Updated by the Author, 2014) [37].

has been on the increase from 230,000 in 1971 to 1.18 million in 2007 [27].

\subsection{Data Collection and Analysis}

\subsubsection{Field Data}

During the field study a handheld Global Positioning System (GPS) with an accuracy level of $+/-10 \mathrm{~m}$ was used to identify the coordinate of features and training samples in the study area which were integrated into the GIS environment. In-depth interview was carried out to capture information from the officers in charge of urban development in "Ondo State Ministry of Housing and Urban Development" and "Akure South Urban and Regional Planning Office”. This was to solicit information based on their years of experiences on the identi- 
fication, problems, impacts and factors responsible for urban sprawl and also the management/monitoring of the sudden growth. The sample size for the in-depth interview was $100 \%$ population which was all the Directors in the Ministry of Housing and Urban Development. Another 100\% sample size was taken in the Local Government office in Akure Area Office of Urban and Regional Planning. Therefore, a total of thirteen officers were interviewed. Questionnaires were administered to assess the perception of the populace on the trend and impact of urban sprawl using the Slovin principle, [23] which suggests that:

$$
\text { Sample population }=\frac{N}{1+N e^{2}}
$$

where $N=$ total targeted population, $e=$ confidence level ( 0.05 for $95 \%)$.

Stratified random sampling technique was used to administer the questionnaire. The division was based on the number of wards with sprawl location(s), subsequently, only fewer than 200 copies of questionnaire were returned.

\subsubsection{Remotely Sensed Data}

Satellite imageries (Landsat TM 1986, 1991, ETM+ 2002, 2011) of the study area were acquired from Land Satellite Programme of the National Aeronautics and Space Administration (NASA), (http://landsat.gsfc.nasa.gov/). The satellite imageries were subjected to digital image processing (DIP) and each band of the imageries was filtered using the $3 \times 3$ median filter. This was done to reduce fragmentation and to clearly identify the various land cover in the study area after [8]. The $3 \times 3$ median spatial filter is applied to reduce the "salt and pepper" noise. Once this is done the pixels are then clearly identify and assigned various land cover classes during the classification process. It ensures that objects to be classified are more identifiable for classification.

$$
0_{i, j}=I_{i-1, j-1} * K_{1}+I_{i-1, j} * K_{2}+\cdots+I_{i+1, j+1} * K_{9}
$$

where $i$ is the row, $j$ is the column and $K$ is the filter kernel.

Maximum likelihood classifier was the algorithm used to classify the imageries. This was done by training pixel based on multivariate probability density function (pdf) of the classes of interest [29]. The classes of interest used were modified after [8] [30] [31]. This was modified into (3) four classes as Built up area, Agro-Forest, High Forest and Water Body. Built-up area (include all human constructions of any kind such as settlement, roads, infrastructures, etc.); Agro-Forest (includes all degraded forest, mixed farming and forest land, and all farmland surfaces), High Forest (An area of land covered with mature trees and other plants growing close together), Water Body (Areas covered with water such as dams and rivers). This was accompanied with thorough ground truthing to confirm the classification and to ascertain the location of major land marks as found in the imageries such as boundaries, facilities and rivers. Each pixel is assigned to the class that has the highest probability (that is, the maximum likelihood). The decision rule is as follows: 


$$
p(X \mid \omega c) p(c) \geq p(X \mid i) p(i)
$$

where $X$ : the spectral multivariate vector;

$p(X \mid \omega c):$ pdf of $X$, given that $X$ is a member of class $\mathcal{C}$,

$p(c)$ : a priori probability of class $c$ in the image;

$i$ : class number among the $m$ number of classes in the image.

The classified imageries were then subjected to accuracy assessment. Stratified random sampling procedure was adopted for assessing the overall accuracy assessment [23]. Points were stratified by the image category and simple random sampling employed within each stratum.

Also, geospatial techniquesoperations were used in this study which is the GIS operations of Overlay, Query and search and GIS Unique Identifier. Correlation (Matrix) Analyses wasalso used to analyze data generated from the questionnaires administered at the identified sprawl locations. This was modeled after [32] model for monitoring urban sprawl in the study area.

\section{Results and Discussion}

Figure 2 and Figure 3 show the subset of the Landsat imageries that were used for this study.

\subsection{Bands Combination}

Seven bands were used for the colour composite map on Landsat TM 1986 and 1991, divided into three bands in visible spectrum, one in the near-infrared, two, in mid-infrared and one in Thermal-infrared. These bands were selected because
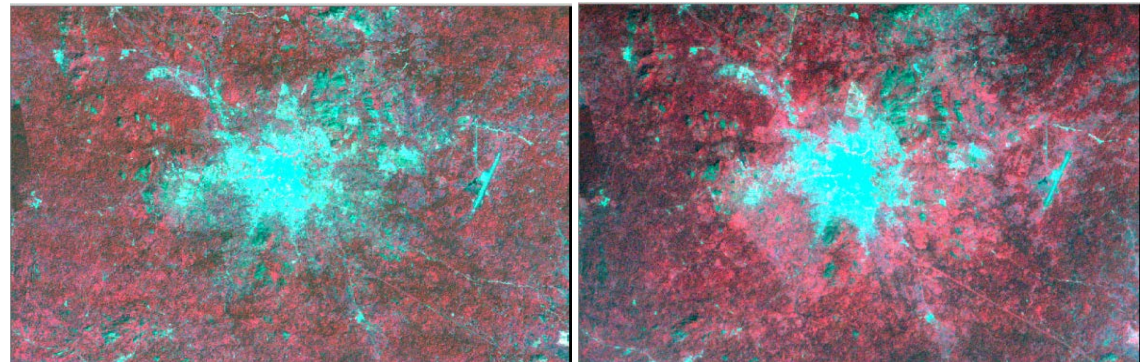

Figure 2. Subset of the Landsat Image of Akure in 1986 and 1991 respectively.

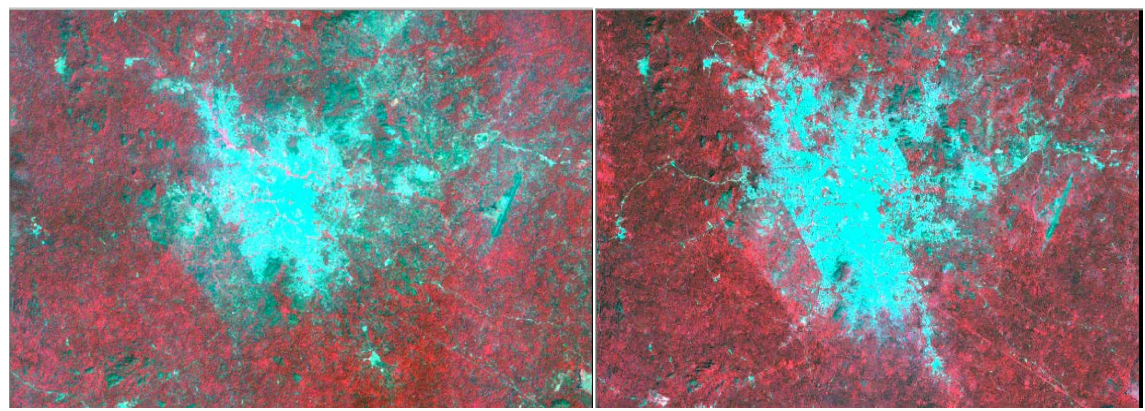

Figure 3. Subset of the Landsat Image of Akure in 2002 and 2011 respectively. Source: LandSat TM 1986; 1991 and LandSat ETM+ 2002; 2011. 
of the sharp contrast the combination produced. The same combination was used for Landsat ETM+ (437), where band 4 is placed on Red, 7 on Green and 3 on blue from the spatial and spectral image characteristics.

\subsection{Digital Image Processing and Analysis}

Figure 4 and Figure 5 and Table 1, show that classified imageries and the land
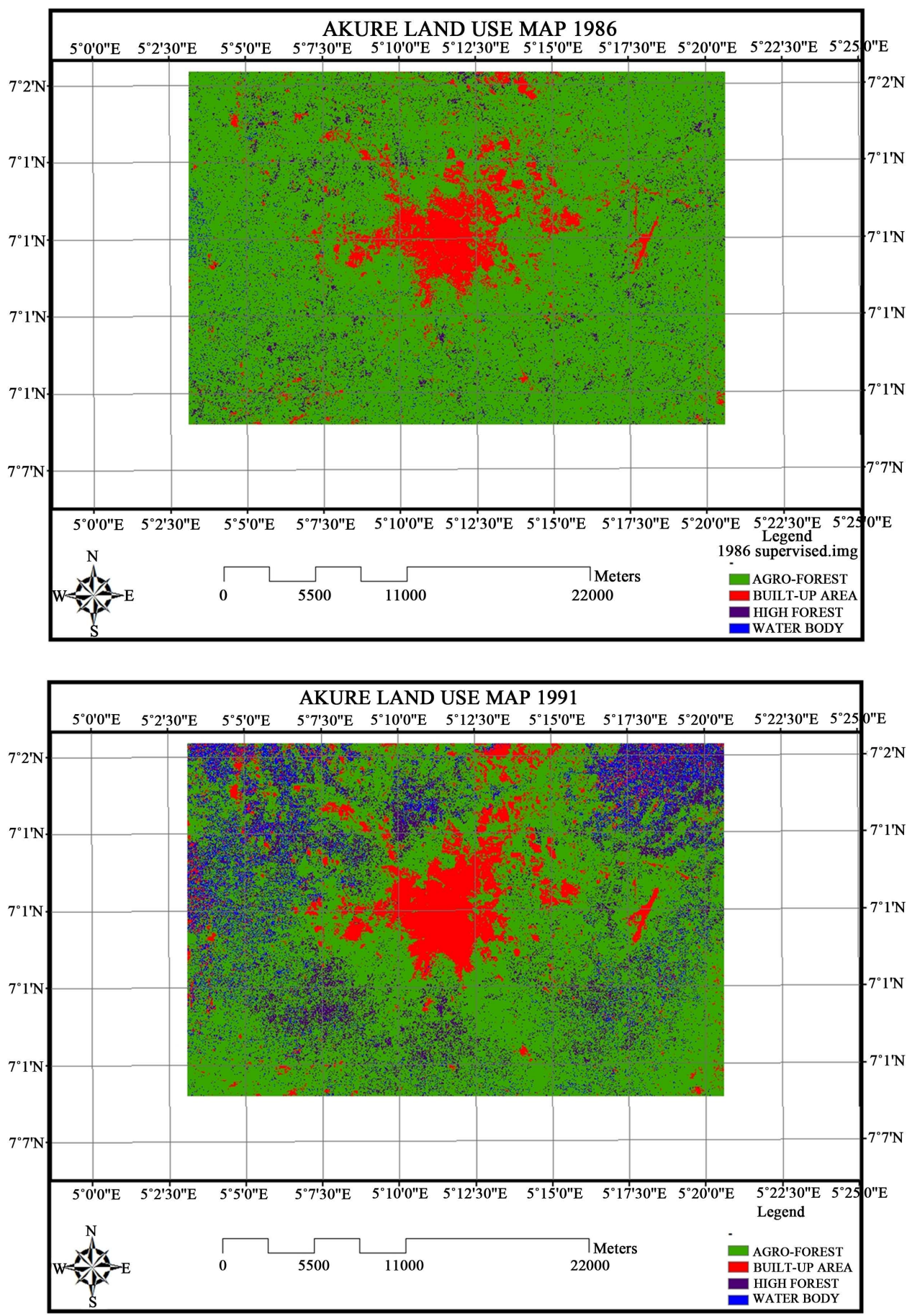

Figure 4. Classified Image of Akure in 1986 and 1991 respectively. 

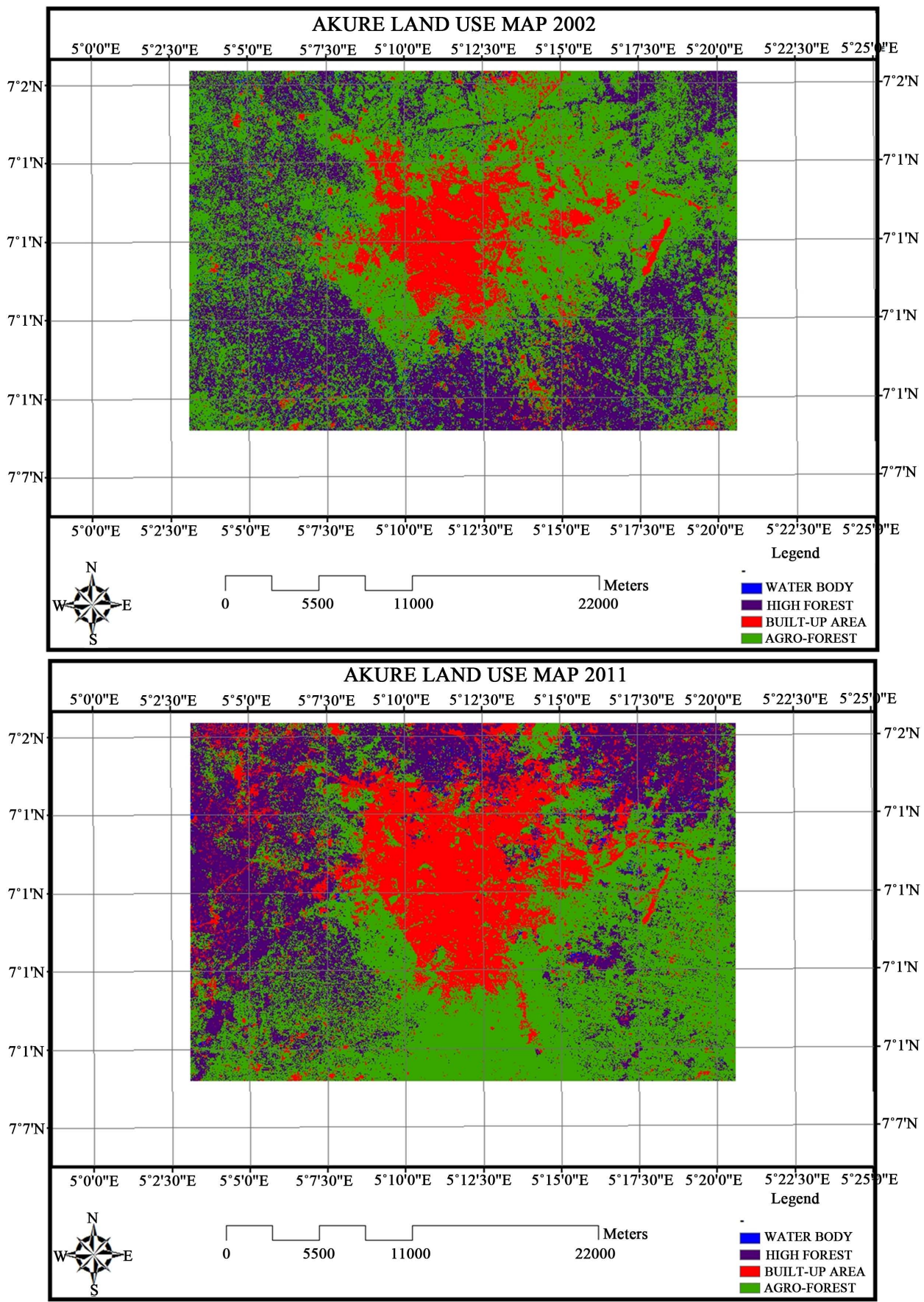

Figure 5. Classified Image of Akure in 2002 and 2011 respectively. Source: LandSat TM 1986; 1991 and LandSat ETM+ 2002; 2011.

use cover change. Analysis indicated that the Built up area had increased rapidly from 5857.54 hectares in 1986 to 8394.21 hectares in 1991 accounting for $43.31 \%$; it then further increased to 8762.76 hectares in 2002 by $4.39 \%$ and to 15073.7 hectares in 2011 by $72.02 \%$. The overall accuracy assessment of the classification for Landsat TM of 1986 was 88\%, while that of Landsat TM 1991 was 88\%. Landsat ETM+ of 2002 and 2011 had an overall accuracy assessment of 92\% and 
Table 1. Trends of urban sprawl in the study area.

\begin{tabular}{|c|c|c|c|c|c|c|c|c|c|c|c|c|}
\hline $\begin{array}{l}\text { Land use } \\
\text { Types }\end{array}$ & 19 & & & 1991 & & & 2002 & & & & 011 & \\
\hline & $\begin{array}{c}\text { Area } \\
\text { (hectares) }\end{array}$ & $\begin{array}{c}\text { Area } \\
(\%)\end{array}$ & $\begin{array}{c}\text { Area } \\
\text { (hectares) }\end{array}$ & $\begin{array}{c}\text { Area } \\
\%\end{array}$ & $\begin{array}{c}\text { Rate of } \\
\text { Change } \\
(\%) \\
1986-1991\end{array}$ & $\begin{array}{c}\text { Area } \\
\text { (hectares) }\end{array}$ & $\begin{array}{c}\text { Area } \\
\%\end{array}$ & $\begin{array}{c}\text { Rate of } \\
\text { Change } \\
(\%) \\
1991-2002\end{array}$ & $\begin{array}{c}\text { Area } \\
\text { (hectares) }\end{array}$ & $\begin{array}{c}\text { Area } \\
\%\end{array}$ & $\begin{array}{c}\text { Rate of } \\
\text { Change } \\
(\%) \\
2002-2011\end{array}$ & $\begin{array}{c}\text { \%Land } \\
\text { Cover } \\
\text { Change } \\
\text { 1986-2011 } \\
\text { (hectares) }\end{array}$ \\
\hline $\begin{array}{c}\text { Built-up } \\
\text { Area }\end{array}$ & 5857.54 & 8.61 & 8394.21 & 12.33 & 43.31 & 8762.76 & 12.87 & 4.39 & 15073.7 & 22.14 & 72.02 & $157.34 \%$ \\
\hline Agro-Forest & 57958.1 & 85.18 & 46913.5 & 68.91 & -19.06 & 37508.9 & 55.09 & -20.05 & 32574.9 & 47.85 & -13.15 & $-43.80 \%$ \\
\hline High Forest & 3311.71 & 4.87 & 7158.78 & 10.52 & 116.17 & 20272.9 & 29.78 & 183.19 & 19606.5 & 28.80 & -3.29 & $492.04 \%$ \\
\hline $\begin{array}{l}\text { Water } \\
\text { Body }\end{array}$ & 916.299 & 1.35 & 5615.37 & 8.25 & 512.83 & 1537.29 & 2.26 & -72.62 & 826.83 & 1.22 & -46.22 & $-9.76 \%$ \\
\hline Total & 68,043 & 100.00 & 68,081 & 100.00 & & 68,081 & 100.00 & & 68,081 & 100.00 & & \\
\hline
\end{tabular}

Source: Landsat TM 1986; 1991 and Landsat ETM+ 2002; 2011. Fieldwork, 2014.

$84 \%$ respectively. Stratified random point generator was used to get 50 random points on each image for the accuracy assessment from Erdas Imagine Software with their coordinates. The assessment was performed through Field work: Topographical map, Google Earth and personal knowledge of the area really assisted in validating the classification with the use of GPS.

These findings proved that Akure had grown overtime. Also, the results of the image classification showed that in 1986, the area covered by water body was $1.35 \%$ (916.299 hectares); this increased to 8.25\% (5615.37 hectares) in 1991 (an interval of 5 years). It was observed that the initial increase was attributed to the degrading of the forest lands as a result of human activities thereby exposing more water body that existed in the forest. This water body in 1991 that covered $8.25 \%$ decreased to $2.26 \%$ in 2002 (an interval of 11 years). This is because the exposed water body was now easily available for human activities and other climatic and environment factors to use it up.

Vector data for the Built-Up Area for the four years were extracted from the satellite image and overlaid with 1986 as the base year (Figure 4).

Landsat (TM) 1986, 1991; (ETM+) 2002 and 2011 imageries used in this study showed that the Built-up area had undergone serious increment between the period of 25 years (1986-2011). The Built-up area increased from 8.61\% occupying an area of 5857.54 hectares in 1986 to $22.14 \%$ occupying an area of 15073.7 hectares in 2011. [20], used Landsat imageries for the Land use Land Cover Analysis of Akure between 1972-2002 and submitted that Built-up area increased rapidly between the period. Also, [33] had the same submission in their study of Urban Expansion and Landuse Change of Akure between 1986 and 2007. The increase in Built-up area based on this study was basically due to migration and urbanization of the city; establishment of Federal University of Technology, Akure; concentration of higher institutions and schools in Akure and increased infrastructural facilities in the city. 
The assessment and analysis of the 1986 to 2011 satellite imageries of the area revealed that there was a decline in the Agro-Forest from 85.18\% covering 57958.1 hectares in 1986 to $47.85 \%$ covering 32574.9 hectares in 2011 while High Forest increased to 2002 and then decline. [28] monitored the Southwestern Nigeria forest with NigerianSat-1 and other satellite imageries and submitted that the Disturbed/Degraded forest increased while the High Forest declined in the area. [34] reported that the mode of incursion into the forest in Southwestern Nigeria is mainly through Agro-Forestry and arable cropland. This finding confirms the view of the [35], that most of the tropical forests cleared each year are due to agricultural practices. It also lends credence to the hypothesis of [36] that deforestation is largely due to the extent of agriculture, involving clearing of land of trees to plant crops [34]. [20] reported that there was a decrease in the Akure vegetation. This was in line with the submission of [33]. The decrease according to this research was as a result of the increase in the Built-up area and the number of farmers that were reduced drastically as a result of the increase in the civil service job. The High Forest increased up to 2002 because the area had been left untouched as a result of the decrease in the number of farmers which made some of the Light Forest turned to High Forest. The High Forest reduced after 2002 owing to the increase in the infrastructural facilities and drastic urban renewal policies of the present government. According to [34], it was reported that the government policy which declares a forest as an inviolate and a protected environment is not being properly monitored in Southwestern Nigeria. This was in agreement with the opinion of [37], that government, especially in the developing countries, have been acting as weak, absentee-landlords over forests that they cannot control. The Water Body increased and later decreased drastically. The initial increase was in line with the submission of [33] while the latter decrease contradicted their argument. The decrease confirmed the findings of [37], who reported a decrease in Akure Water Body till 2002. The reason for the decrease was as a result of human impact of degradation on the Water Body. This result conformed to findings by [38], who reported in his study that Water Body declined between 1986 and 2004 in Southwestern Nigeria. The reason for the initial increase may be that the Water Body areas covered by the forest before have been opened up. It was reported by [20], that the Water Body was stable between 1986 and 2002 in the study area.

\subsection{Field Data: Factors Responsible for Urban Sprawl and Environmental Challenge}

Field data was acquired and integrated with the satellite image data to support its findings on the urban sprawl. Field data also confirmed that Akure had undergone urban sprawl by assessing its factors and impacts. It was discovered from the field observation that the establishment of Akure as the Ondo State Capital attracted various social and infrastructural facilities that further attracts people from different states and local governments for employment, business and edu- 
cation. The relationship between house ownership in the sprawl location and demographic information of the respondents was conducted using inferential statistical tool of Correlation analysis. The variables tested include house ownership in the sprawl location, gender, age, marital status, level of education, number of children, tribe, and changing occupation.

Table 2 revealed an inferential statistic of correlation matrix in analyzing the relationship between the house ownership at the sprawl location and the demographic information of the respondents in the study area. From the Table, the dependent variable is house ownership at the sprawl location while the independent variables are gender, age, marital status, level of education, number of children, tribe and changing occupation. While investigating the factors that are responsible for urban sprawl, it was found that sex, marital status and number of children are significantly responsible for urban sprawl in Akure. Furthermore, the analysis showed that there is a weak negative relationship $(\mathrm{r}=-0.189, \mathrm{p}<$ 0.01 ) between gender and house ownership in the sprawl location. The implication of this analysis was that the less the opposite gender, the more the number of building in the sprawl location. Also, the analysis also found a weak positive relationship $(r=0.343, p<0.01)$ between house ownership in the sprawl location and marital status. This revealed that as more people were getting married, they relocated to the sprawl location for their personal house. In addition, the analysis revealed that there was a weak negative relationship $(r=-0.159, \mathrm{p}<$ 0.05 ) between number of children and house ownership in the sprawl location. The implication of this analysis was that people with less number of children build more houses at the sprawl location.

Findings from this study revealed the trends and factors responsible for urban sprawl between 1986-2011. The analysis of Landsat (TM) 1986, 1991; (ETM+) 2002 and 2011 imageries showed the trends of sprawling in Akure between the period of 25years (1986-2011). According to Figure 4, it revealed that Low density sprawling was predominant during the period 1986-1991. This may be because the factors of population growth were not much. The expansion was just at the edges of the core point or the CBD extending outwardly following the concentric land use model of [39]. Towards the end of 2002, the Town started manifesting Ribbon form of sprawl which encourages the expansion around road network and infrastructural facility following [40], sector theory of urban land use. This confirmed the findings of [37], who reported that Akure is growing along the transportation routes: Akure-Owo express way, Akure-Ijare road, Akure-Ado road to the east, north-west and north-east of the map respectively and all witnessed physical developments. This implied that the development of transportation-infrastructure as a factor of growth in the study area facilitated the growth of the area. This increased economic activities in the study area. On the other hand, the concentration of residential developments along these roads led to the increase in traffic volume experienced on the roads. This has implication on the efficiency of workers and waste valuable working time [37]. This 
Table 2. Correlation matrix of the house ownership at sprawl location and the demographic information of the respondents.

\begin{tabular}{|c|c|c|c|c|c|c|c|c|c|}
\hline \multicolumn{10}{|c|}{ Correlation matrix of the house ownership in the sprawl location and the personal information of the respondents } \\
\hline & & $\begin{array}{l}\text { Do you own } \\
\text { a house } \\
\text { around this } \\
\text { area? }\end{array}$ & Gender & Age & Marital status & $\begin{array}{l}\text { Level of } \\
\text { education }\end{array}$ & $\begin{array}{l}\text { No. of } \\
\text { children }\end{array}$ & Tribe & $\begin{array}{c}\text { Have you changed } \\
\text { occupation? }\end{array}$ \\
\hline \multirow{3}{*}{$\begin{array}{c}\text { Do you own a } \\
\text { house around } \\
\text { this area? }\end{array}$} & $\begin{array}{l}\text { Correlation } \\
\text { Coefficient }\end{array}$ & 1.000 & $-0.189^{\star \star}$ & -0.131 & $0.343^{* *}$ & -0.079 & $-0.159^{*}$ & 0.051 & 0.085 \\
\hline & Sig. (2-tailed) & & 0.008 & 0.066 & 0.000 & 0.273 & 0.029 & 0.478 & 0.248 \\
\hline & $\mathrm{N}$ & 197 & 197 & 197 & 197 & 197 & 190 & 197 & 188 \\
\hline \multirow{3}{*}{ Gender } & $\begin{array}{l}\text { Correlation } \\
\text { Coefficient }\end{array}$ & $-0.189^{\star *}$ & 10.000 & $-0.265^{\star *}$ & -0.040 & -0.006 & -0.026 & 0.039 & 0.012 \\
\hline & Sig. (2-tailed) & 0.008 & & 0.000 & 0.574 & 0.933 & 0.723 & 0.585 & 0.870 \\
\hline & $\mathrm{N}$ & 197 & 200 & 200 & 200 & 200 & 193 & 200 & 191 \\
\hline \multirow{3}{*}{ Age } & $\begin{array}{l}\text { Correlation } \\
\text { Coefficient }\end{array}$ & -0.131 & $-0.265^{\star *}$ & 10.000 & $0.336^{* *}$ & 0.106 & $0.185^{*}$ & -0.015 & $0.205^{\star *}$ \\
\hline & Sig. (2-tailed) & 0.066 & 0.000 & & 0.000 & 0.136 & 0.010 & 0.830 & 0.004 \\
\hline & $\mathrm{N}$ & 197 & 200 & 200 & 200 & 200 & 193 & 200 & 191 \\
\hline \multirow{3}{*}{ Marital status } & $\begin{array}{l}\text { Correlation } \\
\text { Coefficient }\end{array}$ & $0.343^{* *}$ & -0.040 & $0.336^{* *}$ & 10.000 & 0.007 & 0.045 & 0.024 & -0.008 \\
\hline & Sig. (2-tailed) & 0.000 & 0.574 & 0.000 & & 0.917 & 0.530 & 0.731 & 0.913 \\
\hline & $\mathrm{N}$ & 197 & 200 & 200 & 200 & 200 & 193 & 200 & 191 \\
\hline \multirow{3}{*}{$\begin{array}{l}\text { Level of } \\
\text { education }\end{array}$} & $\begin{array}{l}\text { Correlation } \\
\text { Coefficient }\end{array}$ & -0.079 & -0.006 & 0.106 & 0.007 & 10.000 & $0.337^{\star *}$ & $0.378^{* *}$ & $-0.167^{\star}$ \\
\hline & Sig. (2-tailed) & 0.273 & 0.933 & 0.136 & 0.917 & & 0.000 & 0.000 & 0.021 \\
\hline & $\mathrm{N}$ & 197 & 200 & 200 & 200 & 200 & 193 & 200 & 191 \\
\hline \multirow{3}{*}{ No. of children } & $\begin{array}{l}\text { Correlation } \\
\text { Coefficient }\end{array}$ & $-0.159^{\star}$ & -0.026 & $0.185^{\star}$ & 0.045 & $0.337^{* *}$ & 1.000 & $0.353^{\star *}$ & -0.114 \\
\hline & Sig. (2-tailed) & 0.029 & 0.723 & 0.010 & 0.530 & 0.000 & & 0.000 & 0.120 \\
\hline & $\mathrm{N}$ & 190 & 193 & 193 & 193 & 193 & 193 & 193 & 186 \\
\hline \multirow{3}{*}{ Tribe } & $\begin{array}{l}\text { Correlation } \\
\text { Coefficient }\end{array}$ & 0.051 & 0.039 & -0.015 & 0.024 & $0.378^{* *}$ & $0.353^{* *}$ & 10.000 & $-0.275^{\star *}$ \\
\hline & Sig. (2-tailed) & 0.478 & 0.585 & 0.830 & 0.731 & 0.000 & 0.000 & & 0.000 \\
\hline & $\mathrm{N}$ & 197 & 200 & 200 & 200 & 200 & 193 & 200 & 191 \\
\hline \multirow{3}{*}{$\begin{array}{l}\text { Have you } \\
\text { changed } \\
\text { occupation? }\end{array}$} & $\begin{array}{l}\text { Correlation } \\
\text { Coefficient }\end{array}$ & 0.085 & 0.012 & $0.205^{* *}$ & -0.008 & $-0.167^{\star}$ & -0.114 & $-0.275^{\star *}$ & 10.000 \\
\hline & Sig. (2-tailed) & 0.248 & 0.870 & 0.004 & 0.913 & 0.021 & 0.120 & 0.000 & \\
\hline & $\mathrm{N}$ & 188 & 191 & 191 & 191 & 191 & 186 & 191 & 191 \\
\hline
\end{tabular}

${ }^{* *}$ means significant at $0.01 .{ }^{*}$ means significant at 0.05 .

work revealed through correlation matrix analysis that gender, marital status and number of children are significantly responsible for urban sprawl in Akure. This submission was related to the findings of [41], in their work, "Application of IKONOS Satellite Imageries in Monitoring of Urban Land use Change in Ikeja, GRA, Lagos, Nigeria" where they used questionnaire method to generate attribute data to further enhance their information, that factors responsible for 
change in land use include: building type; the use of building and reason for change in the use of building among others. This corroborated the findings of [42], who reported that majority of the farmers in his sample size are married. This account for why this group needed to grow cocoa, which is a cash crop so as to be able to meet the financial requirements of their families. The married couples in this work, moved to the sprawl locations where they get land so cheap and get their houses built. [42], submitted that farmers were persons between the ages of 31 and 40 years while very few farmers were well over 50 years. The implication of the dominance of persons within the age bracket of 31 and 40 was that farming activity was particularly taken by persons who are still very active. These results conformed to the findings in this work, where the age bracket of 30 - 40 years moved most to the sprawl locations for their houses. This finding also agreed with [43], contention that the most significant demographic change in the 1990s was the substantial reduction in the number of farmers over the age of 65 years. Gender was another factor responsible for urban sprawl in Akure according to this study. This related to the findings of [42], who submitted that, the distribution of respondents who degraded forest by sex were $66.05 \%$ and $33.05 \%$ for male and female respectively.

\subsection{Database Creation for Monitoring Urban Sprawl (DBMUS)}

Database was created with features of each layer stored in separate table as feature class which were later combined together to form a comprehensive Database. The feature classes are Local Government, Wards, Road network, Water bodies, Settlement. All these are linked to the base table to form the Monitoring Urban Sprawl (MUS) Database.

\subsubsection{Analysis: Overlay and Query}

Overlay operation places two spatial features on each other based on spatial reference to give their spatial locational relationship. In this work, the built-up areas of the four satellite imageries (1986-2011) were carved out of the supervised classification. These were overlaid with Landsat (TM) 1986 placed on (TM) 1991. This was further placed on (ETM+) 2002 and 2011. These satellite imageries were overlaid to determine the trends of the urban sprawl in Akure according to Figure 6. To test the geospatial database created for this study, it was subjected to some spatial search. Figure 7(b) shows the settlements with major occupation as farming. From the search, 36 settlements were discovered. This query was used to show the capability of this database to answer question pertaining to all the entities of the database.

\subsubsection{Unique Identifier}

This was tested on the Akure MUS where a place was identified through this tool and the information about it was shown in Figure 8. Every attribute of the feature at this point (location) is shown in the dialog box. 


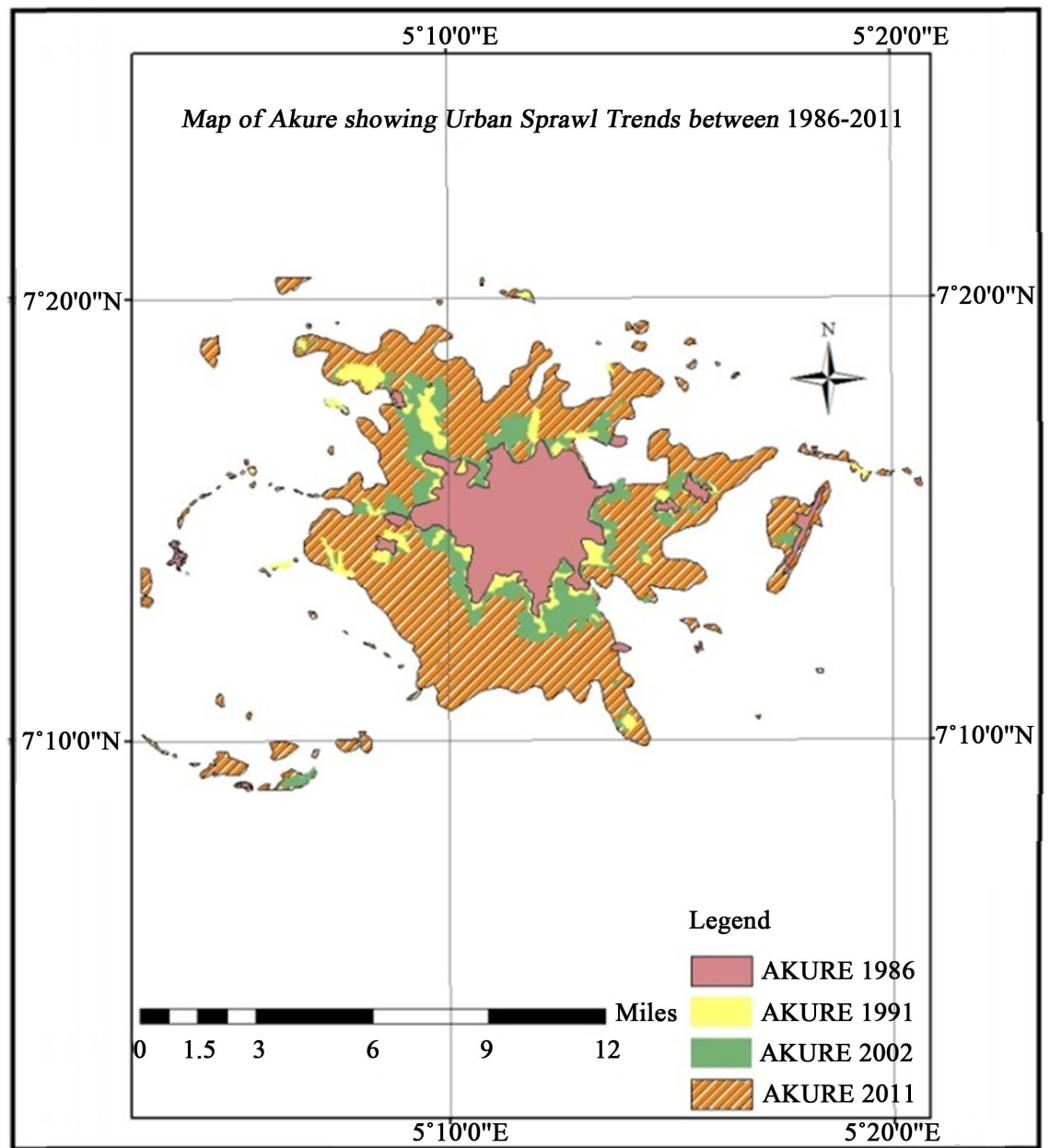

Figure 6. Akure Built-Up Areas Overlay (1986 -2011) to show the Trends of Urban Sprawl.

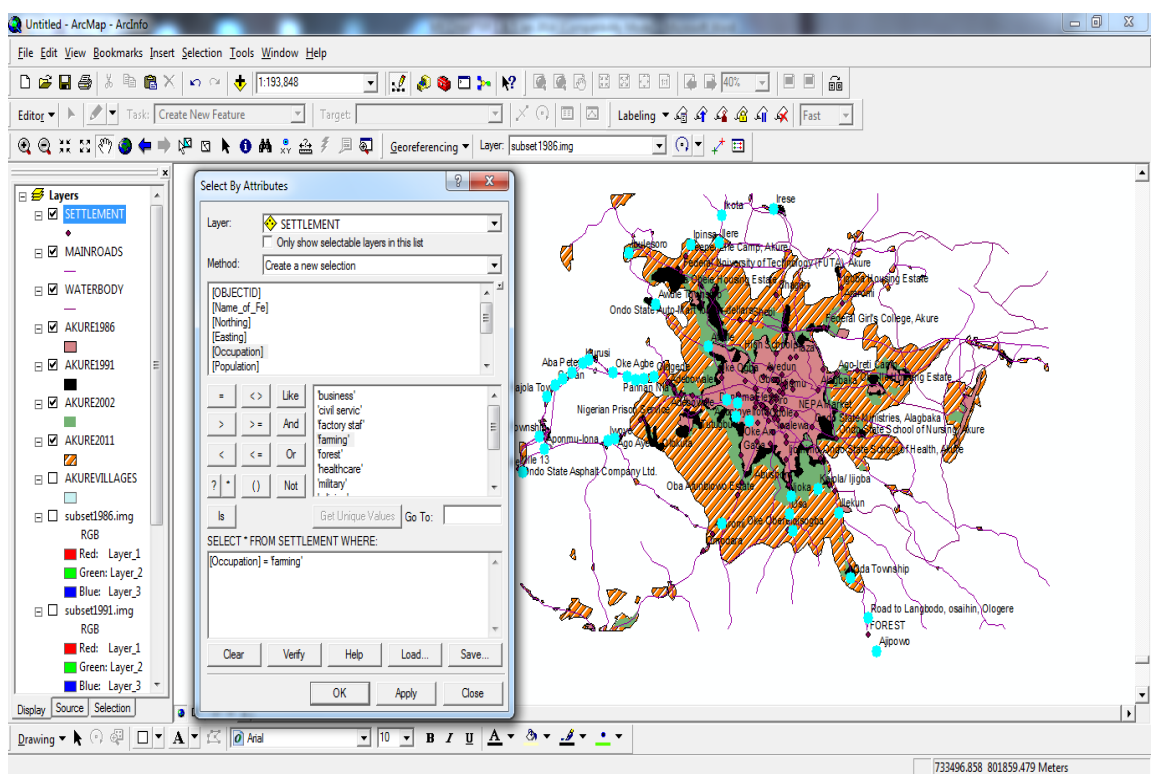

Figure 7. Spatial Search Result showing settlements with farming as their occupation. 


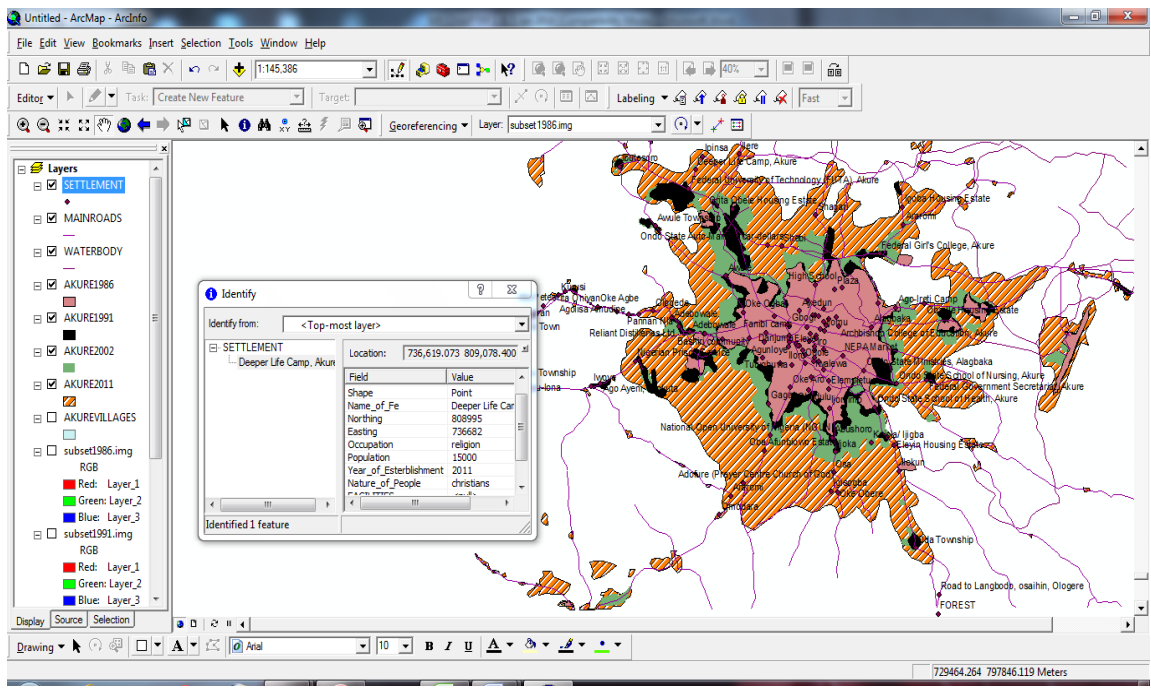

Figure 8. Spatial Search Result Showing Unique identifier result of a feature.

This study developed a geospatial database for monitoring urban sprawl in Akure. The Database was tagged Database for Monitoring Urban Sprawl (DBMUS). The features of each layer were stored in separate table as feature class which were later combined together to form a comprehensive Database. The feature classes are Local Government, Wards, Road network, Water bodies, Settlement etc. All these were linked/joined to the base table to form the Monitoring Urban Sprawl (MUS) Database. The table were populated with the data acquired from the field (geometric and attribute) after taken care of necessary formatting and editing. The entities identified were used to form a relational database in ArcMap GIS. Both the attribute and spatial data were linked together to generate queries that can solve spatial problems. The database in this work was developed in ArcMap GIS which conformed to findings by [39], who followed [32] model, in designing database in ArcMap GIS in his work "Assessment of Spatio-Temporal Trends of Urban Sprawl in Mubi Adamawa State (1976-2006)". Query, overlay, GIS identifier and other analysis were tested in his work just as they were tested in this work where a "feature" was identified through GIS identifier tool and every attribute about it were displayed through a dialog box as shown in Figure 8. Overlay Operation Analysis was also carried out.

\section{Summary and Conclusions}

Geo-information based assessment of the impact of Urban Sprawl in Akure, Southwestern Nigeria using Remote Sensing and Geographic Information Systems (GIS) Techniques had been carried out. Considering the dynamic nature of Urban Sprawl, the use of satellite imageries and Global Positioning System (GPS) has shown the great potentials that the new tools have.

Though, urban sprawl and expansion is something unavoidable. The emer- 
gence of haphazard development has shown the unplanned nature of the sprawl area and therefore, the need to manage the rapid expansion and growth in the town and the settlements around it require pragmatic approach to urban planning and management using modern technology. The study had generated geo-spatial information which can be used to direct urban development ahead of urban pressures, to the appropriate area. The databases generated both spatial and non spatial information that will be useful in managing the rapid growth and expansion through integration with Geographic Information System. To this end, establishment of Remote Sensing and GIS Centers in the State and Local Governments need to be encouraged. The database or Geospatial information like rate of expansion, facilities, utilities and services, percentage change in built-up areas are stored. The information in the database can be retrieved and updated at any time needed. This modern technology feature of GIS makes it suitable for monitoring urban sprawl and growth in Nigerian growing cities.

\section{Acknowledgements}

We appreciate the support of the Institute of Ecology and Environment Studies, Obafemi Awolowo University for the platform to carry out this research.

\section{References}

[1] Peiser, R.B. (2001) Decomposing Urban Sprawl. Town Planning Review, 72, 275-298. https://doi.org/10.3828/tpr.2001.72.3.275

[2] Glaeser, E.L., Kolko, J. and Saiz, A. (2001) Consumer City. Journal of Political Economy, 1, 27-50. https://doi.org/10.1093/jeg/1.1.27

[3] Allen, J. and Lu, K. (2003) Modeling and Prediction of Future Urban Growth in the Charleston Region of South Caro Lina: A GIS-Based Integrated Approach. http://www.consecol.org/vol8/iss2/art2

[4] Mabogunje, A.L. (1974) Towards an Urban Policy in Nigeria. Nigeria Journal of Economic and Social Studies, 16, 85-97.

[5] Menon, N. (2004) Urban Sprawl-A Developing Country Approach. WSCSD, Yale University.

[6] Hathout, S. (2002) The Use of GIS for Monitoring and Predicting Urban Growth in East and West St Paul, Winnipeg, Manitoba, Canada. Journal of Environmental Management, 66, 229-238. https://doi.org/10.1016/S0301-4797(02)90596-7

[7] Nechyba, T.J. and Walsh, R.P. (2004) Urban Sprawl. Journal of Economic Perspectives, 18, 177-200. https://doi.org/10.1257/0895330042632681

[8] Mengistu, D.A. and Salami, A.T. (2007) Application of Remote Sensing and GIS in Land Use Land Cover Mapping and Change Detection in a Part of South Western Nigeria. African Journal of Environmental Science and Technology, 1, 099-109.

[9] Turner II, B.L. (2002) Toward Integrated Land-Change Science: Advances in 1.5 Decades of Sustained International Research on Land-Use and Land Cover Change. In: Steffen, W., Jäger, J., Carson, D.J. and Bradhsaw, C., Eds., Challenges of a Changing Earth, Springer, Berlin, 21-26. https://doi.org/10.1007/978-3-642-19016-2_3

[10] Oyinloye, R.O., Agbo, B.F. and Aliyu, Z.O. (2004) Land Use/Land Cover Mapping 
in Osun State Using NigeriaSat-1 Data.

[11] Adejuwon, J.O. and Jeje, L.K. (1973) Landuse Map of Ife Area. Federal Survey Department, Lagos.

[12] Salami, A.T., Ekanade, O. and Oyinloye, R.O. (1999) Detection of Forest Reserve Incursion in South-Western Nigeria from a Combination of Multi-Data Aerial Photographs and High Resolution Satellite Imagery. International Journal of Remote Sensing, 20, 1487-1497. https://doi.org/10.1080/014311699212579

[13] Salami, A.T. and Akinyede, J. (2006) Space Technology for Monitoring and Managing Forest in Nigeria. In: International Symposium on Space and Forests, United Nations Committee on Peaceful Uses of Outer Space, Vienna.

[14] Makinde, E.O. (2015) Spectral Indices for Detecting Change Trend in Vegetation affected by Hydrocarbon Spillage. https://doi.org/10.7763/ipcbee

[15] Berry, S.S. (1974) The Concept of Innovation and History of Cocoa Farming in Western Nigeria. Journal of African History, 15, 88-95. https://doi.org/10.1017/S0021853700013256

[16] Osunade, M.A.A. (1991) Agricultural Change by Supplanting Process in a Traditional Farming System. International Journal of Ecology and Environmental Sciences, 17, 201-209.

[17] Aloba, O. (1983) Contemporary Research in GeographyatIfe. Ife Research Publications in Geography, 73-86.

[18] Ekanade, O., Salami, A.T. and Aborode, M. (1996) Floristic Changes in the Tropical Rainforest of Southern Nigeria. Malaysian Journal of Tropical Geography, 27, 7-13.

[19] Salami, A.T. (2001) Agricultural Colonization and Floristic Degradation in Nigeria's Ecosystem. The Environmentalist, 21, 221-229.

https://doi.org/10.1023/A:1017939621996

[20] Oyinloye, M.A. and Kufoniyi, O. (2011) Analysis of Landuse Landcover Change and Urban Expansion in Akure, Nigeria. Journal of Innovative Research in Engineering and Sciences, 2, 234-248.

[21] Kaiser, R., Spiegel, P.B., Henderson, A.K. and Gerber, M.L. (2003) The Application Geographic Information Systems and Global Positioning Systems in Humanitarian Emergencies: Lessons Learned, Programme Implications and Future Research. Disasters, 27, 127-140. https://doi.org/10.1111/1467-7717.00224

[22] Kaya, M.N., Seker, S., D.Z. and Goksel, C. (2002) A Case Study of using Remote Sensing Data and GIS for Land Management. Catalca Region. 12th International Congress, 19-26 April 2002, Washington DC.

[23] Omodanisi, E.O., Eludoyin, A.O. and Salami, A.T. (2013) A Multi-Perspective View of the Effects of a Pipeline Explosion in Nigeria. International Journal of Disaster Risk Reduction, 7, 68-77. https://doi.org/10.1016/j.ijdrr.2013.11.002

[24] Adebayejo, A.T. and Abolade, O. (2006) Analysis of Spatial Changes in Ogbomoso City. Journal of the NITP, 19, 35-47.

[25] Kressler, F. and Steinnocher, K. (1996) Changes Detection in Urban Area using Satellite Images and Spatial Mixture Analysis. International Achieves of Photogrammetry and Remote Sensing, 31, 379-383.

[26] Balogun, E.E. and Salami, A.T. (1995) Global and Regional Climate Changes and Variability: Evidence of Climate in Africa and Nigeria.

[27] National Population Commission (NPC) (2007) Nigeria 2006 Census Provisional Results. National Population Commission, Abuja. 
[28] Omodanisi, E.O. (2013) Resultant Land Use and Land Cover Change from Oil Spillage using Remote Sensing and GIS. Research Journal of Applied Sciences, Engineering and Technology, 6, 2032-2040.

[29] USEPA (2001) Why Should We Be Concerned about Sprawl? The Environmental Protection Agency.

[30] Anderson, et al. (1976) A Land Use and Land Cover Classification System for Use with Remote Sensor Data. Geological Survey Professional Paper No. 964, U.S. Government Printing Office, Washington DC, 28.

[31] Igbokwe, J.I. and Emengini, E.J. (2004) GIS in Management of Electricity Distribution Network. A Case Study of Onitsha North L.G.A. http://www.gisdevelopment.net/application/urban/overview/power/index.htm

[32] Kufoniyi, O. (1998) Database Design and Creation. In: Ezeigbo, C.U., Ed., Principles and Applications Geographic Information System, Department of Surveying, UNILAG, Lagos, 62-63.

[33] Balogun, I.A., Adeyewa, D.Z., Balogun, A.A. and Morakinyo, T.E. (2011) Analysis of Urban Expansion and Land Use Changes in Akure, Nigeria, using Remote Sensing and Geographic Information System (GIS) Techniques. Journal of Geography and Regional Planning, 4, 533-541.

[34] Salami, A.T. and Balogun, E.E. (2006) Utilization of NigeriaSat-1 and Other Satellites for Forest and Biodiversity Monitoring in Nigeria. A Monograph Published by National Space Research and Development Agency (NASRDA), Federal Ministry of Science and Technology, Abuja, 31-32.

[35] World Bank (1991) Forest Sector Policy Paper. The World Bank, Washington DC.

[36] Bilsborrow, R.E. (1994) Population, Development and Deforestation: Some Recent Evidence in Population, Environment and Development. United Nation, New York, 117-134.

[37] Oyinloye, et al. (2013) Urban Growth in an Administrative City: A Case Study of Akure, Nigeria. Scottish Journal of Arts, Social Sciences and Scientific Studies. http://scottishjournal.co.uk

[38] Salami, A.T. (2006) Monitoring Nigerian Forest with NigeriaSat-1 and Other Satellites.

[39] Tammi (2011) Assessment of Spatio-Temporal Trends of Urban Sprawl in Mubi Adamawa State (1976-2006). M.Sc. Thesis, Department of Geography, Obafemi Awolowo University, Ile-Ife.

[40] Colby, C.C. (1933) Centrifugal and Centripetal Forces in Urban Geography. Annals of the Association of American Geographers, 23, 475-482.

[41] Oyinloye and Kufoniyi (2013) Application of IKONOS Satellite Images in Monitoring of Urban Landuse Change InIkeja, GRA, Lagos. Nigeria International Journal of Engineering Science Invention, 2, 1-10. http://www.Ijesi.Org

[42] Ering, et al. (2013) Socio-Demographic Characteristics of Cocoa Farmers and Cocoa Production in Etungand Ikom Local Government Areas of Cross River State, Nigeria. Scottish Journal of Arts, Social Sciences and Scientific Studies. http://scottishjournal.co.uk

[43] Frawley, J. and Phelan, G. (2003) Changing Agriculture: Impact on Rural Development. Rural Economy Research Centre Dublin, Dublin. 